\title{
ENHANCING STUDENTS' READING COMPREHENSION THROUGH KWL TECHNIQUE
}

\author{
Sri Fatmaning Hartatik and Emielda Shendita Putri \\ IKIP Budi Utomo Malang \\ fatmaning_aja@yahoo.co.id emieldashenditaputri@gmail.com
}

\begin{abstract}
Abstrak
Penelitian Tindakan Kelas (PTK) ini bertujuan untuk meningkatkan kemampuan membaca siswa kelas x di SMK PGRI Pakis-Malang dalam memahami teks naratif. Penelitian ini perlu dilakukan karena hasil dari preliminary study menunjukan bahwa siswa mengalami kesulitan dalam memahami teks naratif. Selain itu, informasi dari guru menunjukan bahwa siswa memiliki motivasi yang rendah dan kurang bias bekerjasama dalam pembelajaran membaca teks naratif. Dengan menggunakan instrumen yang berupa kuesioner, lembar observasi, catatan lapangan, dan tes yang diterapkan pada dua siklus, ditemukan bahwa teknik KWL mampu meningkatkan kemampuan siswa dalam memahami teks naratif. Secara kualitatif, terbukti bahwa siswa lebih antusias dalam mengikuti pelajaran karena mereka memeliki kesempatan berinteraksi dengan teman sejawat, serta memiliki pengalaman baru dalam belajar. Secara kuantitatif, terbukti bahwa 25 siswa dari 27 siswa memiliki nilai kemampuan membaca yang melebihi KKM sekolah. Penemuan ini memberi informasi bagi para pendidik yang menghadapi persoalan yang sama untuk mencoba mengadopsi ataupun mengadaptasi teknik KWL dalam proses pembelajaran
\end{abstract}

Kata Kunci: Teknik, KWL, Kemampuan Membaca, Teks Naratif

Reading is obviously our inseparable activity. This is so because we do it anytime and anywhere; we read magazine at home; we read labels in our kitchen, we read journals in campus; and we read direction in the streets. Indeed, reading is part of our life. Therefore, reading is put in school curriculum in order to enable the students to comprehend any readers that they will find. In higher level reading, students are not only taught how to decode, process of uttering letter combinations into audible discourse, but also how to comprehend the text. Jeans (2011) points out that there are two affecting factors in reading comprehension: cognitive aspects and affective aspect. Further he explains that cognitive aspects include decoding, vocabulary and grammar mastery, and comprehending. Decoding is a connecting letter strings to the corresponding units of speech that they represent to make sense of print. Differently, vocabulary and grammar are connected components to make a language work either in written manner or spoken manner. Comprehension, in the other hand, is as a process of understanding and interpreting what is printed on a written discourse. Still according to Jeans (2011), the second aspect which influence one's comprehension is an affective aspect; this 
includes motivation, attitude, and interest onto the texts and the readers' feeling about the texts.

In line with Jeans (2011), Karang (2014:7) points out that there are three elements which cannot be separated in reading comprehension activity; they are the reader, the text, and the activity or purpose of reading. It implies that reading comprehension involves the ability of the reader in finding out the main ideas or specific information of the text by using their knowledge on the meaning of the words and how the words are structured. Besides, comprehending a text involves strategies that the students learn to use when they are reading independently. These reading strategies will help them to stick to their reading purposes.

Regarding the above definition of reading comprehension, it can be seen that reading is a complex process which involves many factors and elements. Therefore, it is not surprising anymore to know some students fail in reading class. This phenomenon also occurred at SMK PGRI Pakis, Malang, particularly in the tenth grade. The tenth graders of SMK PGRI Pakis seemed to have difficulties in comprehending reading texts, especially in reading narrative text. The problems were identified through informal interview with the teacher as well as through the distributed narrative comprehension test. The result of the interview and narrative comprehension test showed that students found difficulties in identifying the generic structure of the text and interpreting the message behind the text.

Since reading is one of important skills in students' life, it was so crucial to solve the problems faced by the tenth graders of SMK PGRI Pakis, Malang. In this case the researcher proposed to conduct Classroom Action Research (CAR) by using KWL technique to improve students' comprehension on narrative text.

The selection of KWL technique was based on some considerations. First, in response to the issue of cooperative learning, where the students are the center of teaching and learning process, KWL technique was designed and believed to be able to promote students' ability in a-team-work (Ogle, 1986). Secondly, previous study conducted by Jumria (2010), who applied KWL (KnowWant-Learn) technique to improve the students' reading achievement at SMA Negeri, proved that KWL technique could improve students' reading comprehension significantly. Third, the experimental research that examined the effectiveness of KWL technique conducted by Hermansyah (2014) gave evidence that this technique was proved to be effective to be used in reading class. Based on those three reasons, the researchers believed that the tenth graders' 
problems in comprehending narrative text can be solved.

Discussing about KWL, Ogle (1986), the designer of KWL, explains that KWL stands for Know-Want-Learn. Further he explains that K (know) refers to the students' prior knowledge on the given topic. The students' prior knowledge will help them to understand the reading text. Next, $\mathrm{W}$ (want to learn) is aimed at triggering students' curiosity about a text. Differently, L (learn) refers to a space which allows the students to reflect, and conclude what they have learned. To bring this technique into the class, the researcher put specific questions in each chart of KWL in order to help the students to do their assignments. The KWL chart used in this research is presented in this following chart.

\begin{tabular}{|c|c|c|}
\hline $\begin{array}{c}\text { K } \\
\text { (What We Know) }\end{array}$ & $\begin{array}{c}\text { W } \\
\text { (What We Want } \\
\text { To Know) }\end{array}$ & $\begin{array}{c}\text { L } \\
\text { (What We've } \\
\text { Learned) }\end{array}$ \\
\hline $\begin{array}{l}\text { Things that we } \\
\text { know about this } \\
\text { story: } \\
1 \ldots \ldots \ldots \ldots \ldots \ldots \ldots \\
\ldots \ldots \ldots \ldots \\
2 \ldots \ldots \ldots \ldots \ldots \ldots \\
\ldots \ldots \ldots \ldots \ldots \ldots \\
\\
4 \ldots \ldots \ldots \ldots \ldots \ldots \ldots\end{array}$ & $\begin{array}{l}\text { By reading this } \\
\text { story, we want to } \\
\text { know about: } \\
\text { 1. Who are the } \\
\text { characters of } \\
\text { the story } \\
\text { 2. What is the } \\
\text { setting of the } \\
\text { story? } \\
\text { 3. What is the } \\
\text { orientation of } \\
\text { the story? } \\
\text { 4. What is the } \\
\text { conflict of the } \\
\text { story? } \\
\text { 5. How does the } \\
\text { story end? }\end{array}$ & $\begin{array}{l}\text { We can conclude } \\
\text { that: } \\
\text { The characters of the } \\
\text { story are..... } \\
\text { The story happened } \\
\text { in.... } \\
\text { The conflict of the } \\
\text { story is..... } \\
\text { The story ended..... } \\
\text { The message behind } \\
\text { the story is...... }\end{array}$ \\
\hline
\end{tabular}




\section{Research Design}

As the purpose of this research is improving students' reading comprehension on narrative text, the design of this research is Classroom Action Research. This research involved 27 students at the tenth grade of SMP PGRI Pakis, Malang. Since the class did not belong to the researchers, the researchers performed a collaborative classroom action research in which the researchers were the planners and observers, while the teacher was the actor, the one who taught the students by using KWL. In collecting the data the researchers used some instruments as observation sheets, field notes, questionnaires, and reading test. The observation sheets and field notes had function to collect qualitative data in forms of students' attitude record during the class. Besides, one of the observation sheets functioned as a means to check whether the teacher had applied KWL technique as it was planned in teaching scenario and lesson plan. Differently, the reading test was used to gather quantitative data in the form of students' reading scores. In conducting the research, the researchers followed Kemmis and Taggart (2000:595). The flowchart of the research is presented in this following figure.

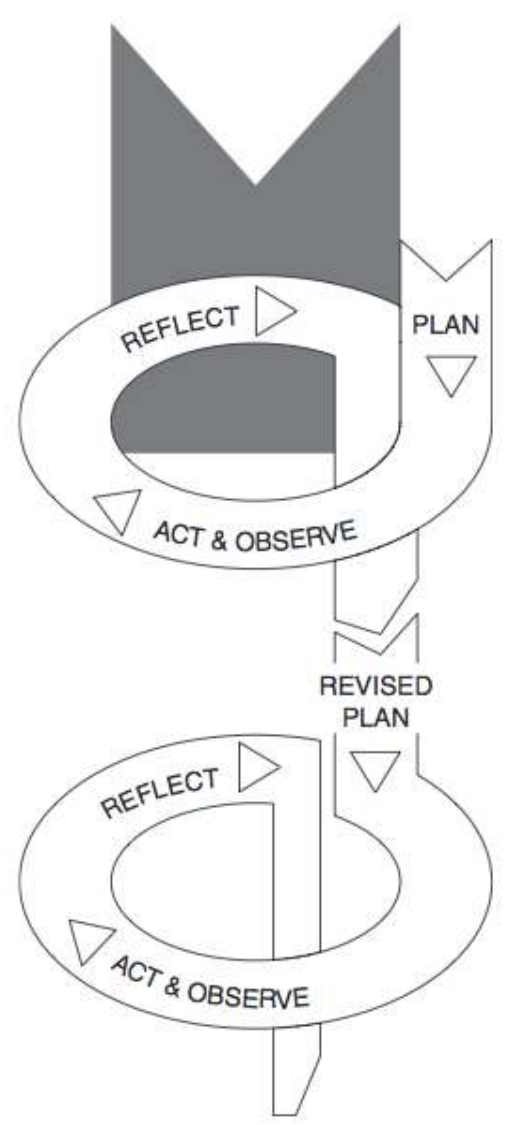

Figure 1.1 Classroom Action Research by Kemmis and Taggart (1990:595)

Before conducting the research the researchers were planning the action. In planning section, there were several things that the researchers did. First, the researchers conducted library review; this was done to give the researchers better insights about KWL so there will be no misconception about the technique. Next, he researcher constructed lesson plans. To make sure that the lesson plans and teaching scenario would be on the right track, the researchers discussed the lesson plans with some lecturers and peers having adequate knowledge on reading comprehension 
domain. Next step was preparing the teaching materials, questionnaires, interview guides and reading test. To make sure that the instruments were valid, the researchers validated the instrument to two reading experts. Finally, the researchers socialized the lesson plans, teaching scenario, and teaching materials to the teacher.

The next steps of the research were acting and observing. In this case the teacher acting the plan based on the lesson plan and the researchers observing the action. In observation phase, the two researchers played different parts; the first researcher observing whether the teacher was on the tract or not, meanwhile the second researcher observing the students' attitude and performance during the class by using field notes and observation sheets.

The last step was reflecting the action. This was done by analyzing the results from questionnaires, field notes, and reading test before comparing the final result with the criteria of success, one of which was $85 \%$ students' score were above the minimum passing grade.

Basically, the implementation of KWL in teaching narrative text had contributed good effect toward students' achievements. The improvement, however were not too significant. This was so because amongst 27 students only $63 \%$ of them passed the minimum passing grade, while the rest were still under the average. Accordingly, the implementation of cycle II needed to be carried on. In order to contribute significant achievement, some modifications were made. The modifications were done by modifying the model text, selecting narrative text which had familiar topic. Another change that was made was in brain storming section, the students were given longer time to explore their prior knowledge.

\section{Finding and Discussion}

There were two kinds of findings in this research. The first one is qualitative finding. It covered the results of questionnaires and field notes. The results from the questionnaires showed that $100 \%$ of the students agreed that this technique allowed them to experience new classroom atmosphere. Next, $92 \%$ or 25 of them agreed that during the implementation of KWL technique they had chances to share and to have good interaction with their classmates. In addition, $85 \%$ of them stated that this technique helped them to understand the generic structure of narrative text. Still the result of questionnaires, $88 \%$ of the students admitted that this technique eased the student to understand the content of the text. Finally, 24 students confirmed that by getting involved in classroom activities the students felt that they could understand the message behind the story. The results revealed from 
the distributed questionnaires were also in accordance with the researchers' note. Based on the notes, the researchers noticed that during the implementation of KWL technique, the students looked enthusiastic in doing their assignments. Besides, the students also seemed to be able to build their ability in a team-work.

The next finding was in the form of quantitative data which were manifested in the form of students reading score. The detailed students' score from cycle I and cycle II can be seen in table 1 and Table 2 .

Table 1. Students' Reading Scores in Cycle I

\begin{tabular}{|c|c|c|c|c|c|c|c|c|c|}
\hline \multirow{2}{*}{ No } & \multirow{2}{*}{ Name } & \multirow{2}{*}{$\begin{array}{l}\text { Individual } \\
\text { Score }\end{array}$} & \multicolumn{6}{|c|}{ Quality } & \multirow{2}{*}{ Categorize } \\
\hline & & & $\mathbf{E}$ & VG & $\mathbf{G}$ & $\mathbf{E}$ & $\mathbf{L}$ & $\mathbf{V L}$ & \\
\hline 1 & A.M.S & 60 & & & & $\sqrt{ }$ & & & Unsuccessful \\
\hline 2 & A.H & 50 & & & & & $\sqrt{ }$ & & Unsuccessful \\
\hline 3 & B.K.A & 80 & & $\sqrt{ }$ & & & & & Successful \\
\hline 4 & D.E.R.N & 40 & & & & & & $\sqrt{ }$ & Unsuccessful \\
\hline 5 & H.H & 80 & & $\sqrt{ }$ & & & & & Successful \\
\hline 6 & M.A & 80 & & $\sqrt{ }$ & & & & & Successful \\
\hline 7 & M.Y.D & 60 & & & & $\sqrt{ }$ & & & Unsuccessful \\
\hline 8 & M.P & 80 & & $\sqrt{ }$ & & & & & Successful \\
\hline 9 & M.R & 50 & & & & & $\sqrt{ }$ & & Unsuccessful \\
\hline 10 & M.A.F & 90 & $\sqrt{ }$ & & & & & & Successful \\
\hline 11 & M.S & 80 & & $\sqrt{ }$ & & & & & Successful \\
\hline 12 & M.Y.P & 30 & & & & & & $\sqrt{ }$ & Unsuccessful \\
\hline 13 & M.SO & 60 & & & & $\sqrt{ }$ & & & Unsuccessful \\
\hline 14 & N.S & 80 & & $\sqrt{ }$ & & & & & Successful \\
\hline 15 & N.M.S & 80 & & $\sqrt{ }$ & & & & & Successful \\
\hline 16 & N.W & 90 & $\sqrt{ }$ & & & & & & Successful \\
\hline 17 & P.S.A & 100 & $\sqrt{ }$ & & & & & & Successful \\
\hline 18 & P.B.V & 80 & & $\sqrt{ }$ & & & & & Successful \\
\hline 19 & R.R.P & 50 & & & & & $\sqrt{ }$ & & Unsuccessful \\
\hline 20 & R.P.H & 50 & & & & & $\sqrt{ }$ & & Unsuccessful \\
\hline 21 & R.A & 50 & & & & & $\sqrt{ }$ & & Unsuccessful \\
\hline 22 & S.D.T & 40 & & & & & $\sqrt{ }$ & & Unsuccessful \\
\hline 23 & S.F & 90 & $\sqrt{ }$ & & & & & & Successful \\
\hline 24 & S.S & 80 & & $\sqrt{ }$ & & & & & Successful \\
\hline 25 & S.PU & 80 & & $\sqrt{ }$ & & & & & Successful \\
\hline 26 & T.W & 70 & & & $\sqrt{ }$ & & & & Unsuccessful \\
\hline 27 & W.C.L & 70 & & & $\sqrt{ }$ & & & & Unsuccessful \\
\hline \multicolumn{2}{|c|}{ Total } & 1850 & 4 & 10 & 2 & 3 & 6 & 2 & \\
\hline \multicolumn{2}{|c|}{ Average } & 68 & & & & & & & \\
\hline
\end{tabular}


Table 2 Students' Reading Score in Cycle 2

\begin{tabular}{|c|c|c|c|c|c|c|c|c|c|}
\hline \multirow{2}{*}{ No } & \multirow{2}{*}{ Name } & \multirow{2}{*}{$\begin{array}{l}\text { Individual } \\
\text { Score }\end{array}$} & \multicolumn{6}{|c|}{ Quality } & \multirow{2}{*}{ Category } \\
\hline & & & $\mathbf{E}$ & VG & $\mathbf{G}$ & $\mathbf{E}$ & $\mathbf{L}$ & VL & \\
\hline 1 & A.M.S & 80 & & $\mathrm{~V}$ & & & & & Successful \\
\hline 2 & A.H & 80 & & $\sqrt{ }$ & & & & & Successful \\
\hline 3 & B.K.A & 80 & & $\sqrt{ }$ & & & & & Successful \\
\hline 4 & D.E.R.N & 80 & & $\sqrt{ }$ & & & & & Successful \\
\hline 5 & H.H & 90 & $\sqrt{ }$ & & & & & & Successful \\
\hline 6 & M.A & 70 & & & $\mathrm{~V}$ & & & & Unsuccessful \\
\hline 7 & M.Y.D & 90 & $\sqrt{ }$ & & & & & & Successful \\
\hline 8 & M.P & 100 & $\sqrt{ }$ & & & & & & Successful \\
\hline 9 & M.R & 90 & $\sqrt{ }$ & & & & & & Successful \\
\hline 10 & M.A.F & 80 & & $\sqrt{ }$ & & & & & Successful \\
\hline 11 & M.S & 80 & & $\sqrt{ }$ & & & & & Successful \\
\hline 12 & M.Y.P & 100 & $\sqrt{ }$ & & & & & & Successful \\
\hline 13 & M.SO & 80 & & $\sqrt{ }$ & & & & & Successful \\
\hline 14 & N.S & 80 & & $\sqrt{ }$ & & & & & Successful \\
\hline 15 & N.M.S & 80 & & $\sqrt{ }$ & & & & & Successful \\
\hline 16 & N.W & 100 & $\sqrt{ }$ & & & & & & Successful \\
\hline 17 & P.S.A & 80 & & $\sqrt{ }$ & & & & & Successful \\
\hline 18 & P.B.V & 100 & $\sqrt{ }$ & & & & & & Successful \\
\hline 19 & R.R.P & 100 & $\sqrt{ }$ & & & & & & Successful \\
\hline 20 & R.P.H & 90 & $\sqrt{ }$ & & & & & & Successful \\
\hline 21 & R.A & 60 & & & & $\sqrt{ }$ & & & Unsuccessful \\
\hline 22 & S.D.T & 80 & & $\sqrt{ }$ & & & & & Successful \\
\hline 23 & S.F & 80 & & $\sqrt{ }$ & & & & & Successful \\
\hline 24 & S.S & 100 & $\sqrt{ }$ & & & & & & Successful \\
\hline 25 & S.PU & 80 & & $\sqrt{ }$ & & & & & Successful \\
\hline 26 & T.W & 90 & $\sqrt{ }$ & & & & & & Successful \\
\hline 27 & W.C.L & 80 & & $\sqrt{ }$ & & & & & Successful \\
\hline \multicolumn{2}{|r|}{ Total } & 2.290 & 11 & 14 & 1 & 1 & & & \\
\hline \multicolumn{2}{|c|}{ Average } & 85,1 & & & & & & & \\
\hline
\end{tabular}

From the above data display it can be seen how KWL technique had influenced the students' achievement both qualitatively and quantitatively. Qualitatively this technique had promoted students' motivation, interest, and their ability to learn cooperatively within a team. This finding is in accordance to the objectives of KWL technique which was designed by Ogle (1986) to enable the students gain their interest and their team work ability. In term of quantitative, this technique had improved the students' 
comprehension on narrative text. This was shown by the classroom grade average which reached 85,1 ; this meant that the students had passed the school minimum passing grade. This quantitative finding supported Jumriah's (2010) research whose finding proved that KWL technique had significantly improved students' reading score. Furthermore, the quantitative finding of this research also highlighted the effectiveness of KWL technique in an experimental research delivered by Hermansyah (2014). All in all, KWL technique was proven to be a good technique to be applied in language learning class; therefore it will be worth for language teachers to consider this technique in their teaching and learning process.

\section{Conclusion and Suggestion}

Based on data analysis and data display, it can be concluded that KWL technique can improve students' comprehension on narrative text as long as the teaching and learning process are well prepared. In addition, the selection of teaching material which evocates the students' prior knowledge on the topic should be wisely considered. Accordingly, the students will understand the topic of the discussion easily. Furthermore, the data speak that KWL technique has also fostered positive classroom atmosphere. This is very important because positive classroom atmosphere plays important role in language learning classroom.

From the aforementioned conclusion, some suggestions are made for several parties; they are stakeholders, teachers, and further researchers. For stakeholders, it is suggested that they pay more attention to teachers' professional development so the teacher are able to improve their teaching skills and solve teaching and learning problems by applying current issues in teaching and learning domain, one of which is KWL technique. For teachers who might face similar problems, it is suggested that they adapt or adopt KWL technique used in this research to improve students' language learning ability. For other researchers, since this research was only limited to improving the tenth graders reading ability on comprehending narrative text, further researchers are encouraged to conduct similar research in broader domain or to carry out different research designs, such as qualitative research or research development, to examine KWL technique from different points of view.

\section{References}

Hermansyah, Trimantara. 2014. Keefektifan strategi KWL (Know-Want to knowlearned) terhadap kemampuan membaca kritis dan berfikir kritis siswa sekolah dasar (Online). Retrieved from http://repository.upi.edu/11546/1/T_PD 1201694 Chapter 1.pdf, on January 28,2015 
Jeans, Carla. 2011. Cognitive Factors that Affect Reading Comprehension, (online). Retrieved from http://www.slideshare.net/jeanecarlaon $\mathrm{g} /$ cognitive-factors-that-affect-readingcomprehension on February 19, 2015

Jumria, 2010, Applying of KWL technique to improve reading achievment, (online). Retrieved from http://www.scribd.com/doc/225986328 .html on January $10^{\text {th }}, 2015$

Karang, Putri D. P. 2014, Improving Reading Comprehension through KWL Strategy at the Eighth grade students of SMPN 01 Amlapura (Online). Retrieved from http://unmas-library.ac.id/wpcontent/uploads/2014/06/skripsipdf.pdf on February 15, 2015

Kemis and Taggart. 1990. The Action

Research Planner. Victoria: Deakin University Press

Ogle. D. 1986. A Teaching Model that Develops Active Reading Expository Text. The Reading Instructor, 39 (6), 564-570 